\title{
Assessing the Condition of Coral Reefs and the Indicator Fish (Family: Chaetodontidae) in Coastal Waters of Jayapura City, Papua Province, Indonesia
}

${ }^{1}$ Department of Marine Science and Fisheries. Faculty of Mathematics and Natural Science,

Cenderawasih University Indonesia Corresponding author, Tel.: +6282199801101 Email address: bhamuna@yahoo.com.sg

\author{
Baigo Hamuna ${ }^{1 *}$, John Dominggus Kalor ${ }^{1}$, Adinda Intan Rachmadani ${ }^{1}$
}

\begin{abstract}
The aim of this study was to find out the condition of coral reef coverage and the presence of Chaetodontidae fish in coastal waters of Jayapura City, Indonesia. The observation of coral reef coverage was performed using point intercept transect (PIT) method; meanwhile the observation of the presence of Chaetodontidae fish used visual census method. The result of this study described that coral reef condition in the study site was in severely damage (live coral $0 \%$ ) in the DOK II site at $6 \mathrm{~m}$ depth, moderately damage (live coral $32.00 \% \pm$ $2.13 \%$ to $42.00 \% \pm 13.18 \%$ ) in Kayu Pulo Island and the DOK II at $3 \mathrm{~m}$ depth, and good condition (live coral $56.00 \% \pm 7.48 \%$ to $60.00 \% \pm 5.55 \%$ ) in the Tanjung Kayu Batu. There were 9 Chaetodontidae fish species from Chaetodon genus, Forcipiger genus, and Heniochus genus. The number of Chaetodontidae fish was 95, of which Heniochus acuminatus was the most dominant, as many as 46 individuals.
\end{abstract}

\section{KEYWORDS}

Acropora; Non-Acropora; Butterflyfish; Chaetodontidae; Live coral percentage; Jayapura; Papua

(c))BY-NC-ND $\odot 2019$ Mikołaj Kaczmarski et al.

This is an open access article distributed under the Creative Commons Attribution-NonCommercial-NoDerivs license

\section{INTRODUCTION}

One of the most potential coastal ecosystems and giving more benefits was the coral reef. A coral reef is one of the important habitats that has high biodiversity and gives important benefit for people in many tropical areas. Coral reefs can be found in Indonesian waters because of its tropical climate, which is why it is very suitable for life sustainability and growth of coral reefs (Fadli et al. 2013; Saptarini et al. 2017). Indonesia's biodiversity of coral reefs is the highest in the world, approximately 590 species of hard coral (Veron 2002) and some species of endemic coral (Rudi et al. 2009). More than $95 \%$ of reef species amount that is recorded in Coral Triangle Center is found in Indonesia (Veron et al. 2009).

Pressure toward coral reefs in coastal areas was already in the level of worrying and threatening these resources (Burke et al. 2002). The condition also happened toward the coral reefs in coastal waters of Jayapura City. This could be caused by the coastal water of Jayapura City, which was the center of government and economy, including the center of development in Papua Province that is still in developing progress nowadays. In accordance to the annual reports of the Department of Maritime and Fisheries Affairs of Jayapura City, the area of coral reefs in the coastal water of Jayapura City was only about 12 ha in around the Yos Sudarso Bay waters and Youtefa Bay (DKP Kota Jayapura 2012). If it was compared to the area of other coastal ecosystems, then the area of coral reefs is very small compared to the area of mangrove forests and seagrasses in the coastal waters of the Jayapura City, namely, approximately 233.12 ha (Hamuna \& Tanjung 2018; Rumahorbo et al. 2019) and 110.83 ha (Tebaiy et al. 2014), respectively.

Monitoring the condition of coral reefs could be conducted by several methods. The usage of several satellite im- 
ageries could be conducted for monitoring the coral reefs in a large area (Hedley et al. 2012; Wahidin et al. 2015; Lubis et al. 2018). Monitoring the coral reefs could also be conducted by using the hydroacoustic technology (White et al. 2003; Walker et al. 2008; Hamuna et al. 2018). Both methods generally aimed to map the distribution and changes in area of coral reefs and not to determine the condition of coral reef coverages, coral lifeform, and coral species. The general method that could be used to determine the coral reef conditions, coral lifeforms, and coral species was direct observation by using the transect method (English et al. 1997; Annas et al. 2017; Paulangan et al. 2019). Coral reefs condition could also be related to the abundance of reef fish. Coral fish habitually responds to the habitat changes, mainly in coral reef coverages (Feary et al. 2007). One of the fishes that could be an indicator of coral reef damages was butterflyfish (Chaetodontidae fish) (Kulbicki et al. 2005; Khalaf \& Crosby 2005). There were approximately 130 species of corallivorous fish (kind of fish that consumes live coral reef's tissue) from 11 different families, where half of the amounts were included in Chaetodontidae fish (Cole et al. 2008). Chaetodontidae fish is a type of fish that lives associating with coral reefs and is very sensitive upon changes and damage of coral reefs because it highly relies on coral reefs as food sources and shelters (Titaheluw 2011).

Up to this day, the information about the condition of coral reefs in the coastal water of Jayapura City is very measly. On the other side, the information about their condition is one of the important components in the management of coral reef ecosystems. Therefore, the judgment of location and coral reef conditions is very important to observe, where the obtained information can be beneficial for plans on the management and sustainability of coral reefs in coastal water of Jayapura City. The purpose of this study was to determine the condition of live coral cover in the coastal waters of Jayapura City, Indonesia. The result of this study was expected to be able to portray the condition that coral reefs in coastal water of Jayapura City had and able to be the input in managing the coral reef ecosystems.

\section{MATERIALS AND METHODS}

\subsection{Study area}

This study area in the coastal water of Jayapura City, Indonesia, was conducted in Maret in 2019. Field data collection was carried out at three sites, namely, (1) Kayu Pulo Island (site S1) at coordinates $140^{\circ} 43^{\prime} 11.811^{\prime \prime} E, 2^{\circ} 32^{\prime} 33.66^{\prime \prime S}$; (2) DOK II (site S2) at coordinates $140^{\circ} 43^{\prime} 2.056^{\prime \prime} \mathrm{E}, 2^{\circ} 32^{\prime} 15.52^{\prime \prime} \mathrm{S}$; and (3) Tanjung Kayu Batu (site S3) at coordinates $140^{\circ} 44^{\prime} 52,078^{\prime \prime} E$, $2^{\circ} 32^{\prime} 16,169^{\prime \prime} \mathrm{S}$. The three study sites have different regional characteristics and utilization rates: DOK II and Kayu Pulo Island are close to residential areas, whereas Tanjung Kayu Batu is far from residential areas. DOK II coastal areas are often used as coastal tourism areas by residents of Jayapura City. The study site is presented in Figure 1.

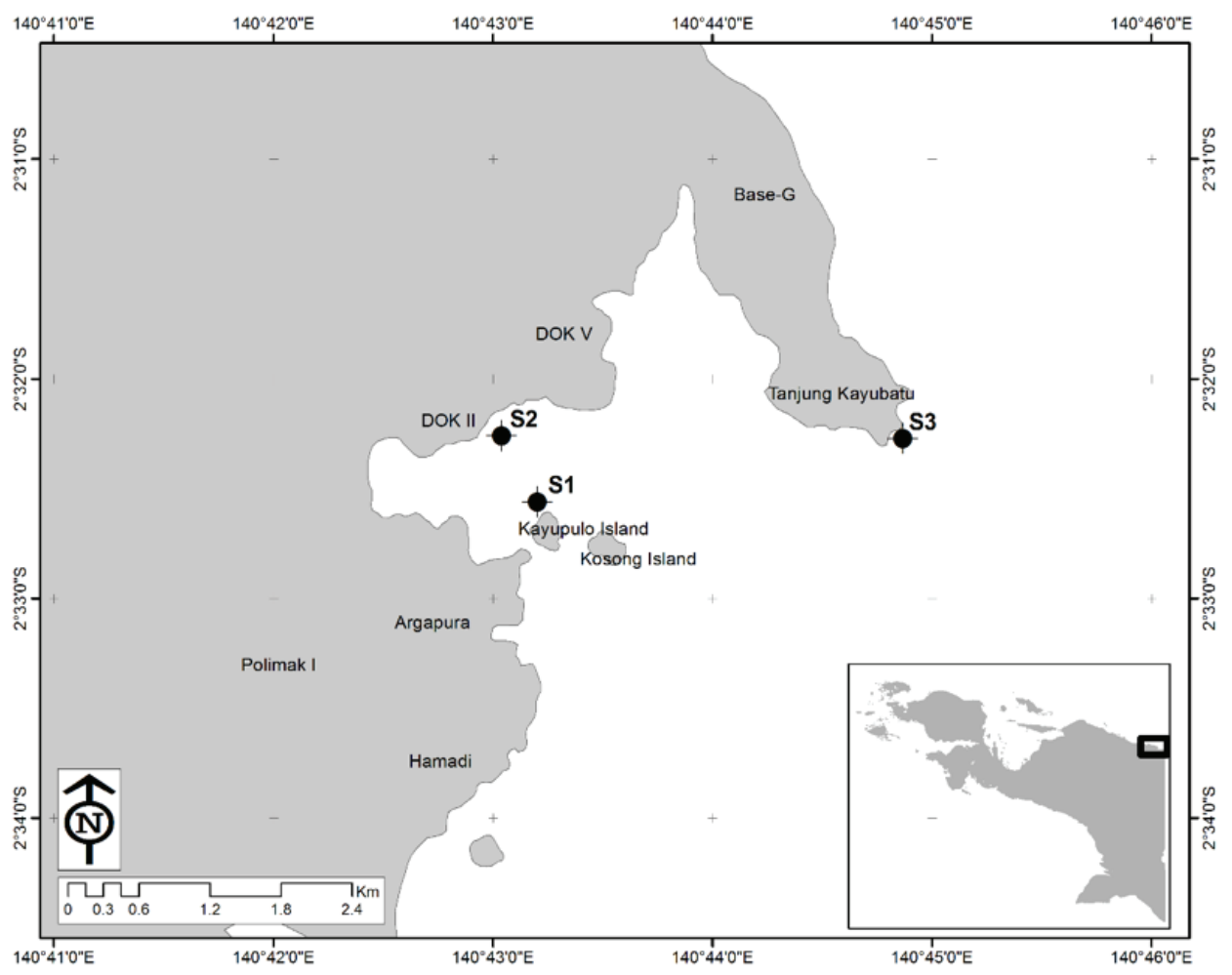

Figure 1. Study sites in coastal waters of Jayapura City, Papua Province, Indonesia; $S 1=$ site $1, S 2=$ site 2, and S3 = site 3 


\subsection{Data collection method}

Data collections toward the presence of Chaetodontidae fish and the coral reefs' coverages were conducted regularly. Both data collections were conducted by performing the SCUBA diving along the transect line with the length of $50 \mathrm{~m}$, in which the placement was parallel to the coastal line in 3 and $5 \mathrm{~m}$ depths.

Data collection of coral reefs was performed using point intercept transect (PIT) method. This method could be used for determining live coral and dead coral coverages (Manuputty \& Djuwariah 2009). This observation was conducted by recording the coral lifeform and other substrates that were found throughout the transect line, where the amount of every coral lifeform and other substrates that were under transect were recorded every $0.5 \mathrm{~m}$. The observation method of Chaetodontidae fish used visual census method (English et al. 1997). The number of Chaetodontidae fish of every species was counted with a limitation of monitoring distance of $2.5 \mathrm{~m}$ on the left and right sides of the transect line. The identification of Chaetodontidae fish species was carried out directly in the field (for a type of familiar fish during the observation) that refers to Allen et al. (2000).

\subsection{Data analysis}

Analysis of coral reefs' coverage was determined in accordance with the percentage of the presence of coral reef lifeform, namely, Acropora and non-Acropora. The percentage of these coral reefs' coverage was calculated using the following equation (Manuputty \& Djuwariah 2009):

$$
\% \text { Coral coverage }=\frac{\text { Number of each coral lifeform }}{100} \times 100 \%
$$

The conditions of coral reefs were determined using the criteria based on State Ministry of Environment Decree of the Republic Of Indonesia No. 4 of 2001 regarding standards of damage of coral reefs, namely, very good (75-100\%), good (50-74.9\%), moderately damage (25-49.9\%), and severely damage (0-24.9\%) (KLH 2001).

The condition of Chaetodontidae fish can be seen from the presence and abundance of Chaetodontidae fish species. The presence of Chaetodontidae fish species can be observed visually, whereas the abundance of Chaetodontidae fish species was calculated using the following formula (English et al. 1997):

$$
\mathrm{FA}=-\sum_{\mathrm{i}=1}^{\mathrm{s}} \frac{\mathrm{n}_{\mathrm{i}}}{\mathrm{A}}
$$

where $F A$ is the abundance of the ith fish species (individuals/ $\left.\mathrm{m}^{2}\right), n_{i}$ is the proportion of the number of the ith fish species, $s$ is the number of fish species, and $A$ is the total of area $\left(250 \mathrm{~m}^{2}\right)$.

\section{RESULTS AND DISCUSSION}

\subsection{Live Coral Coverages}

The condition of coral reefs in the waters can be determined based on the percentage of live coral, which consists of Acropora and non-Acropora lifeforms. The average percentage of the lifeform of coral and substrate in study sites is presented in Table 1. Acropora lifeform in Kayu Pulo Island, DOK II, and Tanjung Kayu Batu sites ranged between 6\% and 7\%, 0\% and $28 \%$, and $16 \%$ and $32 \%$, respectively. Non-Acropora lifeform in the third site ranged between $25 \%$ and $36 \%, 0 \%$ and $7 \%$, and $28 \%$ and $40 \%$, respectively. Especially for DOK II site at 6 $\mathrm{m}$ depth, Acropora and non-Acropora is $0 \%$ because the condition of coral reefs in the depth had been damaged. The other substrate lifeforms, such as soft coral (SC), rubble (R), sand (S), death coral (DC), and death coral with algae (DCA), were found in high numbers in all study sites. Other (OT) lifeforms, such as Diadema sp., anemone, and ascidian, were also found in all study sites.

The result of this study describes the condition of coral reefs coverages in the coastal waters of Jayapura City. According to the State Minister of Environment Decree of the Republic Of Indonesia No. 4 of 2001 (KLH 2001), it was concluded that the condition of coral reefs in coastal waters of Jayapura City, Indonesia, was classified as severely damage to good category (Table 2 ). The live coral coverage of $0 \%$ in DOK II site at $6 \mathrm{~m}$ depth was classified as severely damage category, where the substrate coverage was dominated by rubble and sand. The coral reefs in the Kayu Pulo Island site at 3 and $6 \mathrm{~m}$ depth and the DOK II site at $3 \mathrm{~m}$ depth were classified as moderately damage category, meanwhile the coral reefs in Tanjung Kayu Batu site at $3 \mathrm{~m}$ and $6 \mathrm{~m}$ depth was classified as a good category. The results of this study are not much different from the condition of the coral reefs reported by Dinas Kelautan dan Perikanan Kota Jayapura (Department of Maritime Affairs and Fisheries of Jayapura City), in which the condition of coral reefs had reached out the average damage of $90.00 \%$, which meant $60.00 \%$ of severely damage, $30 \%$ of moderate damage, and only $10.00 \%$ of good condition (DKP Kota Jayapura 2012).

This low percentage of the coverages of coral reefs could result in the lowness of fish resources that lived in coral reefs, even the slightest loss of corals will cause a decrease in fish abundance. The decrease in the fish abundance of some species after the coral reef damage might point out that live coral was an important attribute from the coral reef habitat (Wilson et al. 2006). This thing could happen because live coral is an important habitat for some types of coral fish such as target fish groups, major fish groups, and indicator fish groups (Madduppa et al. 2012). Several impacts of the decrease in coral reef condition or even the loss of coral reefs toward reef fish could come about in a relatively short period of time, for instance, the decrease in physiological condition and reproduction activities (Pratchett et al. 2004), meanwhile for a longer period of time, this could engender the more decrease and lower abundance and diversity of fish (Wilson et al. 2006). 
Table 1. The frequency of the presence of coral lifeform and other substrates in each study site

\begin{tabular}{|c|c|c|c|c|c|c|c|}
\hline Lifeform Category & S1-3 & S1-6 & S2-3 & S2-6 & S3-3 & S3-6 & Total \\
\hline \multicolumn{8}{|l|}{ Acropora: } \\
\hline Acropora branching (ACB) & 0 & 4 & 22 & 0 & 5 & 5 & 36 \\
\hline Acropora digitate (ACD) & 0 & 0 & 6 & 0 & 4 & 7 & 17 \\
\hline Acropora encrusting (ACE) & 6 & 1 & 0 & 0 & 4 & 4 & 15 \\
\hline Acropora tabulate (ACT) & 0 & 2 & 0 & 0 & 19 & 0 & 21 \\
\hline \multicolumn{8}{|l|}{ Non-Acropora: } \\
\hline Coral branching (CB) & 5 & 3 & 0 & 0 & 3 & 0 & 11 \\
\hline Coral encrusting (CE) & 0 & 3 & 0 & 0 & 4 & 0 & 7 \\
\hline Coral massive (CM) & 30 & 7 & 5 & 0 & 13 & 18 & 73 \\
\hline Coral mushroom (CMR) & 1 & 3 & 2 & 0 & 3 & 3 & 12 \\
\hline Coral submassive (CS) & 0 & 7 & 0 & 0 & 5 & 19 & 31 \\
\hline Heliopora $(\mathrm{CHL})$ & 0 & 2 & 0 & 0 & 0 & 0 & 2 \\
\hline Death coral (DC) & 11 & 6 & 11 & 16 & 4 & 5 & 53 \\
\hline Death coral with algae (DCA) & 3 & 3 & 8 & 12 & 1 & 3 & 30 \\
\hline Rubble (R) & 8 & 33 & 30 & 28 & 10 & 8 & 117 \\
\hline Sand (S) & 20 & 19 & 8 & 39 & 16 & 22 & 124 \\
\hline Soft coral (SC) & 10 & 6 & 2 & - & 7 & 2 & 27 \\
\hline Other (OT) & 6 & 1 & 6 & 5 & 2 & 4 & 24 \\
\hline
\end{tabular}

Note: $\mathrm{S} 1-3=$ site 1, depth $3 \mathrm{~m} ; \mathrm{S} 1-6$ = site 1, depth $6 \mathrm{~m} ; \mathrm{S} 2-3$ = site 2, depth $3 \mathrm{~m} ; \mathrm{S} 2-6$ = site 2, depth $6 \mathrm{~m} ; \mathrm{S} 3-3$ = site 3, depth 3 m; S3-6 = site 1 , depth $6 \mathrm{~m}$

Table 2. Percentage of live coral coverage at each study site

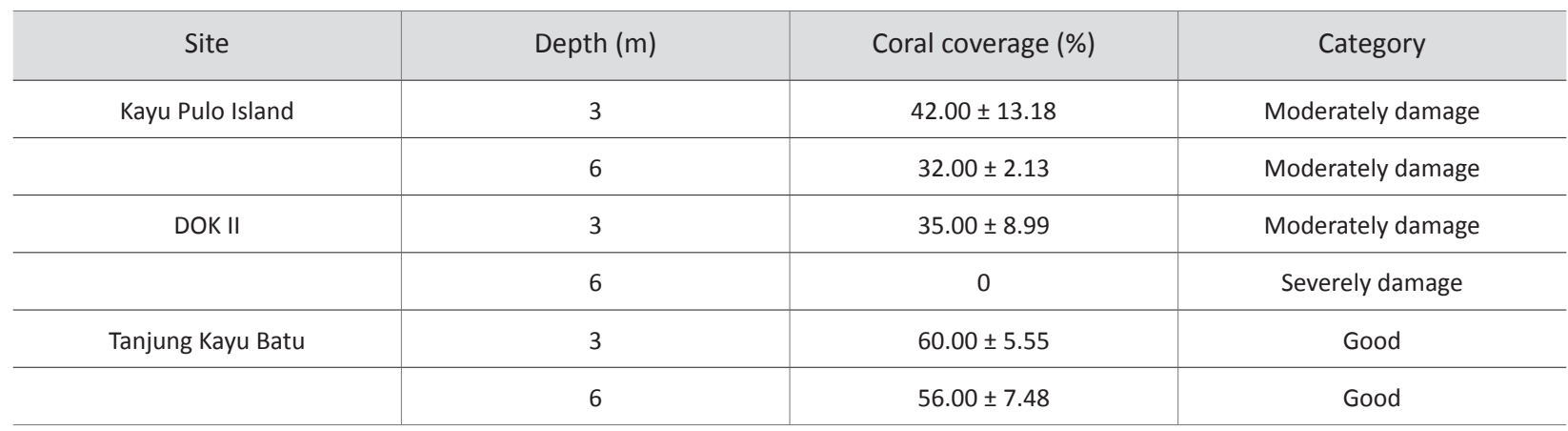

In accordance with the study result, the Rubble lifeform was discovered in a large amount in the Kayu Pulo Island and DOK II sites. This circumstance could describe that high pressure and high interference upon the coral reefs were from human activities. Several activities that negatively impacted directly toward the coral reefs and is still going on up to this day inter alia tourism activities that damaged the environment by stepping on the coral reefs, throwing ship anchor in coral reef areas, and destructive fishing. Similar to the results of this study, the results of a survey conducted by Kubelaborbir (2015) were that the damage upon coral reefs in coastal waters of DOK II (S2 site) was brought by anthropogenic activities, particularly there was no awareness of the utilization of destructive fishing tools (e.g., the utilization of explosives and potassium for fish catching), domestic waste disposal into the sea, and also the existence of sedimentation from Anafri river that empties into that location. Community structures of coral reefs could be affected by the impacts of anthropogenic activity, specifically in a residential area in a coastal area, and destructing fishing activity. The increase in the exploitation level could cause the damage of reef fish habitat that triggers the decrease in reef fish diversity. Excessive and damaging fishing, contamination from runoff, and building construction in the coastal area were the 
Table 3. The presence and abundance of Chaetodontidae fish at each study site

\begin{tabular}{|c|c|c|c|c|c|c|c|c|c|c|}
\hline \multirow{2}{*}{ Species } & \multicolumn{3}{|c|}{ S1 } & \multicolumn{3}{|c|}{ S2 } & \multicolumn{3}{|c|}{ S3 } & \multirow{2}{*}{$\mathrm{n}_{\mathrm{i}}$ (ind) } \\
\hline & 3 & 6 & $\mathrm{FA}_{i}$ & 3 & 6 & $\mathrm{FA}_{i}$ & 3 & 6 & $\mathrm{FA}_{\mathrm{i}}$ & \\
\hline C. auripes & - & - & 0 & - & - & 0 & + & - & 0.012 & 3 \\
\hline C. baronessa & - & - & 0 & + & - & 0.008 & - & + & 0.012 & 5 \\
\hline C. ephippium & - & - & 0 & + & - & 0.004 & - & - & 0 & 1 \\
\hline C. kleinii & + & + & 0.02 & - & - & 0 & + & + & 0.024 & 11 \\
\hline C. octofasciatus & - & - & 0 & - & - & 0 & + & + & 0.024 & 6 \\
\hline C. trifaciatus & + & + & 0.024 & + & - & 0.004 & + & - & 0.004 & 8 \\
\hline F. flavissimus & - & - & 0 & - & - & 0 & + & - & 0.008 & 2 \\
\hline H. acuminatus & + & + & 0.088 & + & - & 0.024 & + & + & 0.072 & 46 \\
\hline H. varius & + & + & 0.028 & + & - & 0.016 & + & - & 0.008 & 13 \\
\hline Total number of fish & 29 & 11 & & 14 & - & & 24 & 17 & & 95 \\
\hline Abundance (ind $\cdot \mathrm{m}^{-2}$ ) & \multicolumn{3}{|c|}{0.160} & \multicolumn{3}{|c|}{0.056} & \multicolumn{3}{|c|}{0.164} & \\
\hline
\end{tabular}

Note: $\mathrm{S} 1$ = Kayu Pulo Island site; S2 = DOK II site; S3 = Tanjung Kayu Batu site; 3 = $3 \mathrm{~m}$ depth; 6 = $6 \mathrm{~m}$ depth; $\mathrm{FA}_{\mathrm{i}}=$ species abundance; + = present; - = absent

most hazardous threats that could lead to the damage of coral reefs of around 20-90\% (Burke et al. 2002, 2012).

\subsection{The presence and abundance of Chaetodontidae fish}

There were 9 indicator fish species of Chaetodontidae family that were found in three study sites during the survey (Table 3). The species of indicator fish that were discovered came from three genus were (1) Chaetodon genus consisted of 6 species Chaetodon auripes, Chaetodon baronessa, Chaetodon ephippium, Chaetodon kleinii, Chaetodon octofasciatus, and Chaetodon trifaciatus; (2) Forcipiger genus consisted of 1 species Forcipiger flavissimus; and (3) Heniochus genus consisted of 2 species Heniochus acuminatus and Heniochus varius. The number of indicator fish that was recorded among all study sites was 95, of which the number of fishes from Heniochus genus, Chaetodon genus, and Forcipiger genus was 59, 34, and 2 individuals, respectively.

Therefore, the lowness of the number of Chaetodontidae fish species that were discovered in this study was being thought to be more influenced by the lack of lifeform diversity of coral reefs that existed in the study site, compared to the percentage of live coral coverages. In accordance with the statement by Siringoringo and Hadi (2013), more diverse conditions of live coral lifeform will support the growth of various types of reef fish. Live coral lifeform in the study site was only 4 for Acropora lifeforms and 6 for non-Acropora lifeforms with a low percentage of cover and were not found in all study locations (except $\mathrm{CM}$ lifeform), including the percentage of branched coral lifeforms ( $A C B$ and CB lifeform) quite low. This condition is probably the cause of the low number of species and individuals of Chaetodontidae fish.

Besides the factor of live coral lifeform diversity, the characteristics of each Chaetodontidae fish species also could determine their existence on coral reefs. For instance, $\mathrm{H}$. acu- minatus was Chaetodontidae fish that was the most discovered during surveys in all study sites. It could be due to this species included in planktivore was usually discovered in groups with a large number of individuals (Titaheluw 2011). H. varius was also found in quite a large number, because the group of $\mathrm{He}$ niochus species was a type of fish that likes to stay in reef slope areas (Bawole 1998), and this circumstance was appropriate with coral reefs in study sites, thus the presence of this species was quite high. C. kleinii is interested in coral reefs in the form of branching, whether as the predation area or as a sheltering area and also many were founded in waters with high brightness levels (Hukom 2001). Chaetodontidae fish species could also be very specialized such as Chaetodon trifascialis that exclusively obtained foods from Acropora hyacinthus species (Pratchett, 2005) and Chaetodon melanotus was similar to soft coral (Cole et al. 2008). C. trifascialis and Chaetodon ornatissimus were not found during the survey because these species preferred good coral reef conditions in which the presence of this species could indicate that the condition of the coral reefs had not disturbance or it was still relatively good (Madduppa 2006).

Besides giving the number of indicator fish, Table 4 also provides the information on the Chaetodontidae fish abundance in coastal waters of Jayapura City. The highest abundance of Chaetodontidae fish around $0.164 \mathrm{ind} \cdot \mathrm{m}^{-2}$ in the Tanjung Kayu Batu site and the lowest was around 0.046 ind $\cdot \mathrm{m}^{-2}$ in the DOK II site. Live coral coverages that were still in a good category in the Tanjung Kayu Batu site impact the higher abundance of Chaetodontidae fish, albeit the number of the abundance was not too different from Kayupulo Island site with the live coral coverages were in moderately damage category. Live coral coverage is an important clue to the number and abundance of reef fish species, including the reef fish from the Chaetodontidae family (Garpe \& Öhman, 2003), where the 
highest fish abundance was very related to the condition of the coverage of live coral, which was still in good condition (Titaheluw 2011). Coral reefs that were still in good condition would provide abundant food sources for Chaetodontidae fish. It was caused by the cycle of Chaetodontidae fish life really depends on the living tissue of coral reefs polyp as a food source (Khalaf \& Crosby 2005). Besides that, the distribution and abundance of reef fish in coral reef areas could be also determined by abiotic factors (Bawole et al. 2014).

\section{CONCLUSIONS}

The result of this study informs regarding the condition of coral reefs in coastal waters of Jayapura City, where coral reefs were confirmed as being in severely damage category to good category. The highness of lifeform rubble could portray that there were high pressures and disturbances toward coral reefs that came from human activities. There were 9 Chaetodontidae fish species from Chaetodon genus, Forcipiger genus, and $\mathrm{He}-$ niochus genus. The number of Chaetodontidae fish was 95, of which Heniochus acuminatus was the most dominant as many as 46 individuals.
The decrease in the condition of coral reef coverages would lead to a decrease in its functions as the habitat and the fish resource provider. This condition indirectly would impact on the decrease in the amount of reef fishery harvests and also the local fishermen's incomes. With good management, it would impact on either increase in the quality of the environment or the ecosystem for the preservation of coral reefs, which surely would immensely impact on the increase in the economic incomes and local society's welfare.

\section{Acknowledgments}

The authors would like to offer particular thanks to the Institute of Research and Community Service, Cenderawasih University that has funded this study through the PNBP Research Grant. The authors also want to thank the Direktorat Polisi Air Baharkam POLRI (DITPOLAIR) Kepolisian Daerah Papua for lending and preparing SCUBA diving equipment during the study and also to students from the Department of Marine Science and Fisheries, Cenderawasih University, for their assistance when collecting field data.
Allen, G.R., Swainston, R. \& Ruse, J. (2000) Marine fishes of South East Asia: a field guide for anglers and divers. Perth: Periplus Edition.

Annas, R.A., Muchlisin, Z.A. \& Sarong, M.A. (2017) Coral reefs condition in Aceh Barat, Indonesia. Biodiversitas, 18(2), 514-519.

Bawole, R., Pattiasina, T.F., Irma E. \& Kawulur, J.J. (2014) Coral-fish association and its spatial distribution in Cenderawasih Bay National Park Papua, Indonesia. AACL Bioflux, 7(4), 248-254.

Bawole, R. (1988) The spatial distribution of Chaetodontidae fish and its role as an indicator of the condition of coral reefs in the waters of Ambon bay. MSc Thesis, Bogor Agricultural University, Bogor, Indonesia. (in Indonesian)

Burke, L., Reitar, K., Spalding, M. \& Perry, A. (2012) Reefs at risk revisited in the coral triangle. Washington: World Resources Institute.

Burke, L., Selig, E. \& Spalding, M. (2002) Reefs at risk in Southeast Asia. Washington: World Resources Institute.

Cole, A.J., Pratchett, M.S. \& Jones, G.P. (2008) Diversity and functional importance of coral-feeding fishes on tropical coral reefs. Fish and Fisheries, 9(3), 286-307.

DKP Kota Jayapura [Dinas Kelautan dan Perikanan Kota Jayapura]. (2012) Laporan Tahunan Dinas Kelautan dan Perikanan Kota Jayapura. Jayapura: Dinas Kelautan dan Perikanan Kota Jayapura. (in Indonesian)

English, S., Wilkinson, C. and Baker, V. (1997) Survey manual for tropical marine resources (2nd ed). Townsville: Australia Institute of Marine Science.

Fadli, N., Kunzmann, A., Von Jutarzenka, K., Rudi, E. \& Muchlisin, Z.A. (2013) A preliminary study of corals recruitment using coral rub- bles substrate in Seribu Island waters, Indonesia. AACL Bioflux, 6(3), 246-252.

Feary, D.A., Almany, G.R., Jones, G.P. \& McCormick, M.I. (2007) Coral degradation and the structure of tropical reef Fish communities. Marine Ecology Progress Series, 333, 243-248.

Garpe, K.C. \& Öhman, M.C. (2003) Coral and fish distribution patterns in Mafia Island Marine Park, Tanzania: fish-habitat interactions. Hydrobiologia, 498(1-3),191-211.

Hamuna, B. \& . Tanjung, R.H.R. (2018) Deteksi perubahan luasan mangrove Teluk Youtefa Kota Jayapura menggunakan citra landsat multitemporal. Majalah Geografi Indonesia, 32(2), 115-122. (in Indonesian)

Hamuna, B., Pujiyati, S., Natih, N.M.N. \& Dimara, L. (2018) Analisis hambur balik akustik untuk klasifikasi dan pemetaan substrat dasar perairan di Teluk Yos Sudarso, Kota Jayapura. Jurnal IImu dan Teknologi Kelautan Tropis, 10(2), 291-300. (in Indonesian)

Hedley, J.D., Roelfsema, C.M., Phinn, S.R. \& Mumby, P.J. (2012) Environmental and sensor limitations in optical remote sensing of coral reefs: Implications for monitoring and sensor design. Remote Sensing, 4(1), 271-302.

Hukom, F.D. (2001) Asosiasi antara komunitas ikan karang (family Chaetodontidae) dengan bentuk pertumbuhan karang di perairan Kepulauan Derawan Kalimantan Timur. Jakarta: P3O-LIPI. (in Indonesian)

KLH (Kementerian Negara Lingkungan Hidup Republik Indonesia). (2001). Keputusan Menteri Negara Lingkungan Hidup Nomor 4 tahun 2001 tentang kriteria baku kerusakan terumbu karang. 
Jakarta: Kementerian Negara Lingkungan Hidup Republik Indonesia. (in Indonesian)

Khalaf, M. \& Crosby, M.P. (2005) Middle East regional science symposium and workshop: Butterflyfish (Family Chaetodontidae) research and monitoring. Aquatic Conservation: Marine and Freshwater Ecosystems, 15, S3-S11.

Kubelaborbir, T.M. (2015) Kondisi eksisting ekosistem terumbu karang di perairan DOK II Kota Jayapura Provinsi Papua. The Journal of Fisheries Development, 2(3), 39-44. (in Indonesian)

Kulbicki, M., Bozec, Y.M. \& Green, A. (2005) Implication of biogeography in the use of butterflyfishes (Chaetodontidae) as indicator for Western and Central Pacific Areas. Aquatic Conservation: Marine and Freshwater Ecosystems, 15, S109-S126.

Lubis, M.Z., Anurogo, W., Hanafi, A., Kausarian, H., Taki, H.M. \& Antoni, S. (2018) Distribution of benthic habitat using Landsat-7 imagery in shallow waters of Sekupang, Batam Island, Indonesia. Biodiversitas, 19(3), 1117-1122.

Madduppa, H.H., Agus, S.B., Farhan, A.R., Suhendra, D. \& Subhan, B. (2012) Fish biodiversity in coral reefs and lagoon at the Maratua Island, East Kalimantan. Biodiversitas, 13(3), 145-150.

Madduppa, H.H. (2006). Bioecological study on eight band butterflyfish (Chaetodon octofasciatus, Bloch 1787) to detect the condition of coral reef ecosystem in East Petondan Island, Seribu Islands, Jakarta. MSc Thesis, Bogor Agricultural University, Bogor, Indonesia. (in Indonesian)

Manuputty, A.E.W. \& Djuwariah. (2009) Method guide point intercept transect (PIT) for community baseline study and coral health monitoring at marine no-take zona area (DPL). Jakarta: COREMAP II-LIPI. (in Indonesian)

Paulangan, Y.P., Fahrudin, A., Sutrisno, D. \& Bengen, D.G. (2019) Distribution and condition of coral reef ecosystem in Tanah Merah Bay, Jayapura, Papua, Indonesia. AACL Bioflux, 12(2), 502-512.

Pratchett, M.S., Wilson, S.K., Berumen, M.L. \& McCormick, M.I. (2004) Sublethal effects of coral bleaching on an obligate coral feeding butterflyfish. Coral Reefs, 23(3), 352-356.

Pratchett, M. (2005) Dietary overlap among coral-feeding butterflyfishes (Chaetodontidae) at Lizard Island, northern Great Barrier Reef. Marine Biology, 148(2), 373-382.

Rudi, E., Elrahimi, S.A., Kartiijaya, T., Herdiyana, Y., Setiawan, F., Shinta, P., Campbell, S. \& Tamelander, J. (2009) Reef fish status in north- ern Acehnese reef based on management type. Biodiversitas, 10(2), 88-93.

Rumahorbo, B.T., Keiluhu, K.J. \& Hamuna, B. (2019) The economic valuation of mangrove ecosystem in Youtefa bay, Jayapura, Indonesia. Ecological Questions, 30(1), 47-54.

Saptarini, D., Mukhtasor \& Rumengan, I.F.M. (2017) Coral reef lifeform variation around power plant activity: Case study on coastal area of Paiton Power Plant, East Java, Indonesia. Biodiversitas, 18(1), 116-120.

Siringoringo, R.M. \& Hadi, T.A. (2013) The condition and distribution of stony corals (Scleractinia corals) in Bangka water. Jurnal IImu dan Teknologi Kelautan Tropis, 5(2), 273-285. (in Indonesian)

Tebaiy, S., Yulianda, F., Fahrudin, A. \& Muchsin, I. (2014). Struktur komunitas ikan pada habitat lamun di Teluk Youtefa Jayapura Papua. Jurnal Iktiologi Indonesia, 14(1), 49-65. (in Indonesian)

Titaheluw, S. (2011) Linkages between coral reefs and Chaetodontidae fish: Implications for management. MSc Thesis, Bogor Agricultural University, Bogor, Indonesia. (in Indonesian)

Veron, J.E.N., Devantier, L.M., Turak, E., Green, A.L., Kininmonth, S., Stafford-Smith, M. \& Peterson, N. (2009) Delineating the coral triangle. Galaxea, Journal of Coral Reef Studies, 11(2), 91-100.

Veron, J.E.N. (2002) Reef corals of the Raja Ampat Islands, Papua Province, Indonesia, Part I: overview of Scleractinia. In: S.A. McKenna, G.R. Allen \& S. Suryadi (Eds.), A marine rapid assessment of the Raja Ampat Islands, Papua Province, Indonesia (pp. 26-36). Washington: Conservation International.

Wahidin, N., Siregar, V.P., Nababan, B., Jaya, I. \& Wouthuyzen, S. (2015) Object-based image analysis for coral reef benthic habitat mapping with several classification algorithms. Procedia Environmental Science, 24, 222-227.

Walker, B.K., Riegl, B. \& Dodge, R.E. (2008) Mapping coral reef habitats in southeast Florida using a combined technique approach. Journal of Coastal Research, 24(5), 1138-1150.

White, W.H., Harborne, A.R., Sotheran, I.S., Walton R. \& Foster-Smith, R.L. (2003) Using an acoustic ground discrimination system to map coral reef benthic classes. International Journal of Remote Sensing, 24(13), 2641-2660.

Wilson, S.K., Graham, N.A.J., Pratchett, M.S., Jones, G.P. \& Polunin, N.V.C. (2006) Multiple disturbances and the global degradation of coral reefs: Are reef fishes at risk or resilient? Global Change Biology, 12(11), 2220-2234. 